\title{
A new genus and species of Muridae (Rodentia) from the Quaternary deposits of the Denizli Basin, South-western Turkey
}

\author{
Hüseyin Erten
}

\begin{abstract}
This paper describes a new genus and species of Muridae, Extrarius orhuni gen. nov. and sp. from the Quaternary terrestrial deposits of the Denizli Basin (South-western Turkey). The circular island shaped neoenterostyle in the lingual part of M1 and complete stephanodonty show a unique combination of apomorphic characters. These initial fossils provide a starting point, and more studies will surely provide more details on the origins of this taxon and its relationship to other taxa in the wider region.
\end{abstract}

Hüseyin Erten. Department of Geological Engineering, Pamukkale University, 20017 Kınıklı-Denizli, Turkey. herten@pau.edu.tr

Keywords: Muridae; New genus; New species; Quaternary; Denizli; Turkey

Submission: 10 March 2016 Acceptance: 13 March 2017

\section{INTRODUCTION}

Erten (2014) studied the terrestrial sediments of the Denizli Basin (South-western Turkey) in terms of small mammals in his Ph.D. dissertation. According to this study, Denizli Basin consists of terrestrial sediments aged from early middle Miocene to Early Pleistocene interval (Erten et al., 2014) (Figure 1). Studies on the Quaternary aged localities of the Denizli Basin generally concern large mammals that are found in the travertines. In the first study on fossils from travertine deposits, Erten et al. (2005) reported on Equus aff. suessen- bornensis, Bos sp. and Dama sp. Boulbes et al. (2014) described more remains of large mammals from these travertines. Also, they revised the fossils previously described by Erten et al. (2005). The new faunal list described by Boulbes et al. (2014) includes Archidiskodon meridionalis meridionalis, Stephanorhinus cf. etruscus, Equus cf. altidens s.I., E. cf. apolloniensis, Metacervoceros rhenanus, Palaeotragus sp., Bovinae gen. and indeterminate bovines. Furthermore, Kappelman et al. (2008) has described the first Homo erectus from Turkey in the same travertine area.

\section{http://zoobank.org/A544F7B3-A7B7-4B5E-8F98-28D8A83B288B}

Erten, Hüseyin. 2017. A new genus and species of Muridae (Rodentia) from the Quaternary deposits of the Denizli Basin, Southwestern Turkey. Palaeontologia Electronica 20.1.12A: 1-7

palaeo-electronica.org/content/2017/1787-quaternary-aged-small-mammals

Copyright: @ March 2017 Society of Vertebrate Paleontology. This is an open access article distributed under the terms of the Creative Commons Attribution License, which permits unrestricted use, distribution, and reproduction in any medium, provided the original author and source are credited.

creativecommons.org/licenses/by/4.0/ 


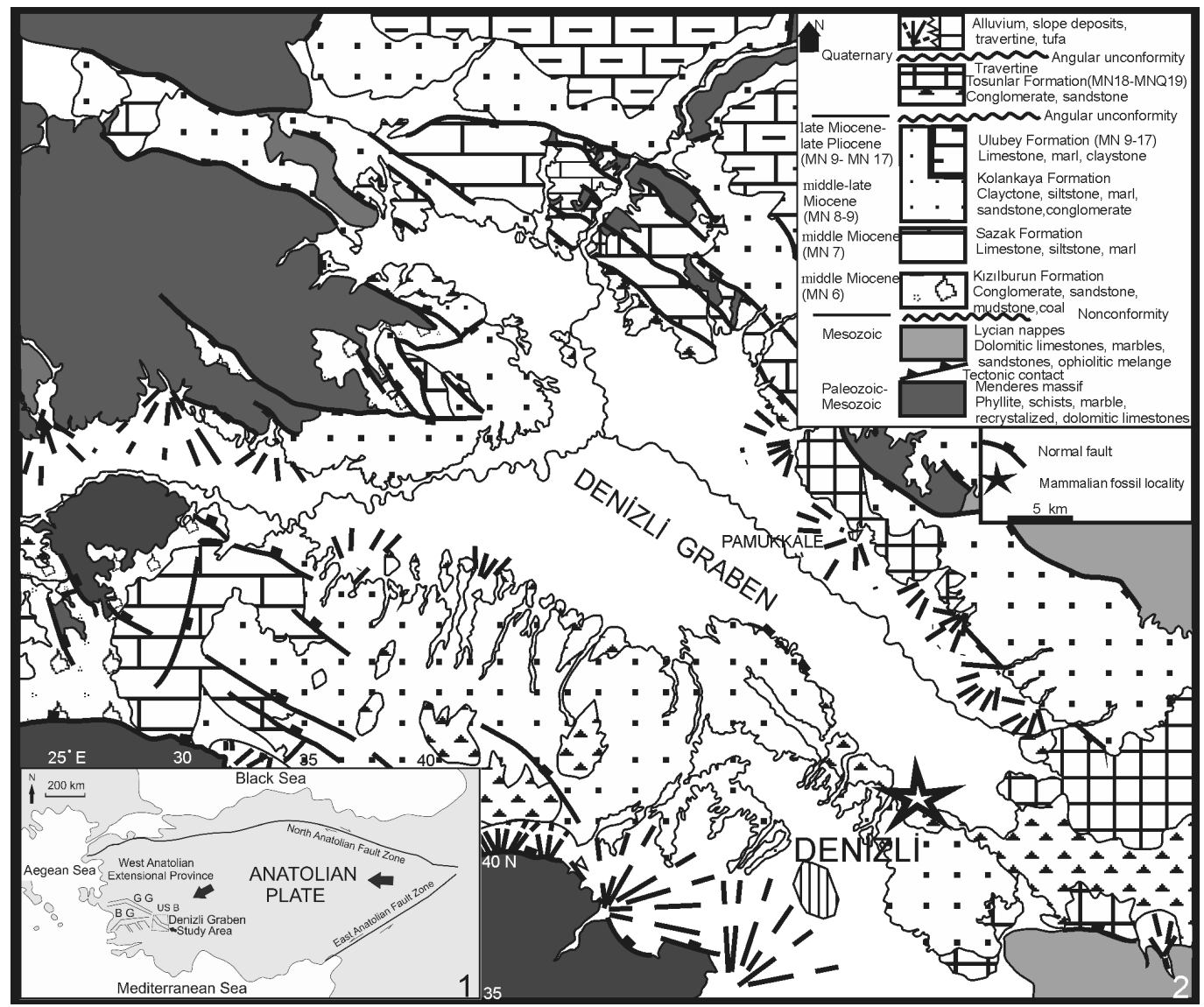

FIGURE 1. 1, Location of the Denizli Basin in western Turkey (modified from Bozkurt, 2003); 2, Geological map of the Denizli Basin modified from Erten et al. (2014) with the position of Gökpınar locality.

Moreover, related to the micromammalian fauna from these sites, a new genus and species has been found as a result of this post-doctoral research in the Gökpınar locality (GOP), which was dated as MNQ18-19 (1.5-2.6 Ma) (Erten et al., 2015). In addition to this new murid, this locality previously yielded Dryomys tosyaensis, Dryomys $\mathrm{sp}$, Mus denizliensis, and Apodemus sylvaticus/flavicollis (Erten et al., 2015). This locality is quite rich in fossils, nevertheless, during follow-up research eight molars ( $3 \mathrm{M} 1 \mathrm{~s}, 2 \mathrm{M} 2,1 \mathrm{~m} 1$ and $2 \mathrm{~m} 2$ ) representing the new murid species were identified and are herein formally described. They are kept as a part of the fossil collection of The Geological Engineering Department at Pamukkale University.

\section{QUATERNARY DEPOSITS OF THE DENIZLI BASIN}

The Gökpınar locality is included in the Tosunlar Formation, which uncomformably lies on the middle Miocene-Pliocene units and it has been described by Şimşek (1984). The bottom part of the formation is composed of conglomerates, sandstones and siltstones that are covered by travertines. The Tosunlar Formation is usually dominated by red and brown colours and locally it may be coloured gray and yellowish. The Tosunlar Formation starts with the alluvium fan and continues upward with fluvial deposits. The unit which shows levels of different thickness and is composed of alternating conglomerate, sandstone, siltstone and mudstone facies including claystones in some places. Within the unit, plant remains, gastropods, reworked shells and fragments of mollusc at older units are quite common (Erten et al., 2015).

Travertines from the Denizli Basin are internally exploited and exported world-wide. Old travertine formations are widely observed in different parts of the basin, especially along its northern parts. The total area of travertines in the basin covers more than $100 \mathrm{~km}^{2}$ whose thickness is sometimes over $75 \mathrm{~m}$ (Erten et al., 2005; Özkul et al., 2013). The depressional field travertines yielded scarce vertebrate fossils in some quarried locali- 
ties. There are various studies on these fossils (Erten et al., 2005; Kappelman et al., 2008; Boulbes et al., 2014). These travertines in Denizli (Turkey), where Homo erectus was also found, were dated by Lebatard et al. (2014) at least 1.1 Ma.

\section{MATERIAL AND METHODS}

The fluvio-lacustrine sediment was screen washed using a stack of sieves of decreasing mesh size $(4 \mathrm{~mm}-0.5 \mathrm{~mm})$. The fossils were then separated from the non-fossiliferous sediments. Finally, they were examined and studied with a stereomicroscope (Olympus SZX9).

The dental nomenclature follows mainly that of Lazzari et al. (2010) (Figure 2). Double axis Mitutoyo measuroscope was used for measuring the maximum length and width of each tooth and the results are given in millimeters (Table 1 ). The upper molars are abbreviated as M1, M2 and M3 while lower molars as $\mathrm{m} 1, \mathrm{~m} 2$ and $\mathrm{m} 3$. The Gökpınar locality is abbreviated as GOP.

\section{SYSTEMATIC PALAEONTOLOGY}

\section{Order RODENTIA Bowditch, 1821 \\ Family MURIDAE Gray, 1821 Genus Extrarius gen. nov.}

Figure 3.1-8

zoobank.org/D78F4C83-C2E5-4DBB-981C-C057EEF9F046

Type species. Extrarius orhuni sp. nov.

Type specimen. left M1 (GOP-5001)

Referred specimens. right M1 (GOP-5002), right M1 (GOP-5003), left M2 (GOP-5004), left M2 (GOP-5005), left m1 (GOP-5006), right m2 (GOP5007), and right $m 2$ (GOP-5008)

Type locality. Gökpınar, Denizli Basin Turkey. Tosunlar Formation, Quaternary

Derivatio nominis. From the Latin word 'Extrarius' meaning "external, outsider," because of the presence of a neoenterostyle on M1, which is an apomorphic character.

Diagnosis. The occlusal surface exhibits complete stephanodonty. The cusps $\mathrm{t} 1, \mathrm{t} 2$ and $\mathrm{t} 3$ have strong connections on M1. A connection in the form of a longitudinal crest exists between $\mathrm{t} 1-\mathrm{t} 5$ and $\mathrm{t} 3-\mathrm{t} 5$. A strong and garland-type connection exists between t4-t5-t6-t9-t8 and t7 or t4-t7 connection is absent while the other cusps are strongly connected. A circular island shaped neoenterostyle is observed in the lingual part of the tooth. tma is absent on $\mathrm{m} 1$, and $c 1$ and $c 2$ are connected to each other (Figure $3)$.

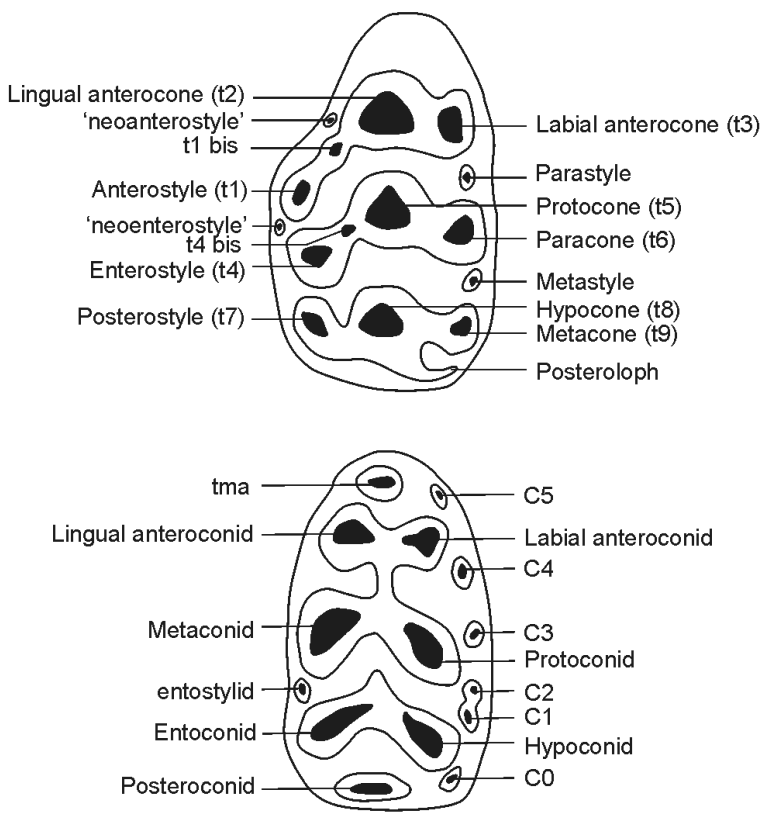

FIGURE 2. Dental terminology of murid upper and lower molars (after Lazzari et. al., 2010).

Extrarius orhuni sp. nov. zoobank.org/F6B0B5ED-51EC-4546-8A9E-BCDE161CCEDA Type specimen, Type locality and Diagnosis. As for genus.

Derivatio nominis. In honour of my son; Orhun Erten.

\section{Description of the Material}

M1. There are three M1 specimens (GOP 50015002-5003) one of which (GOP 5003) is slightly worn and damaged on the back part (Figure 3). One of the complete specimens (GOP 5001) has a complete stephanodonty (on the occlusal face all cups are connected by ridges, Cordy, 1976). t1, t2 and $\mathrm{t} 3$ have strong connections in all specimens. $A$ connection in the form of a longitudinal crest exists

TABLE 1. Material and measurements of Extrarius orhuni nov. gen. and sp. from Gökpınar locality (GOP).

\begin{tabular}{cccc}
\hline Specimen number & Molar & Length & Width \\
\hline GOP -5001 & M1 & 2.07 & 1.28 \\
GOP-5002 & M1 & 2.09 & 1.30 \\
GOP-5003 & M1 & - & 1.26 \\
GOP-5004 & M2 & 1.26 & 1.18 \\
GOP -5005 & M2 & 1.30 & 1.20 \\
GOP -5006 & $\mathrm{m} 1$ & 1.72 & 1.03 \\
GOP -5007 & $\mathrm{m} 2$ & 1.12 & 1.02 \\
GOP -5008 & $\mathrm{m} 2$ & 1.10 & 1.00 \\
\hline
\end{tabular}




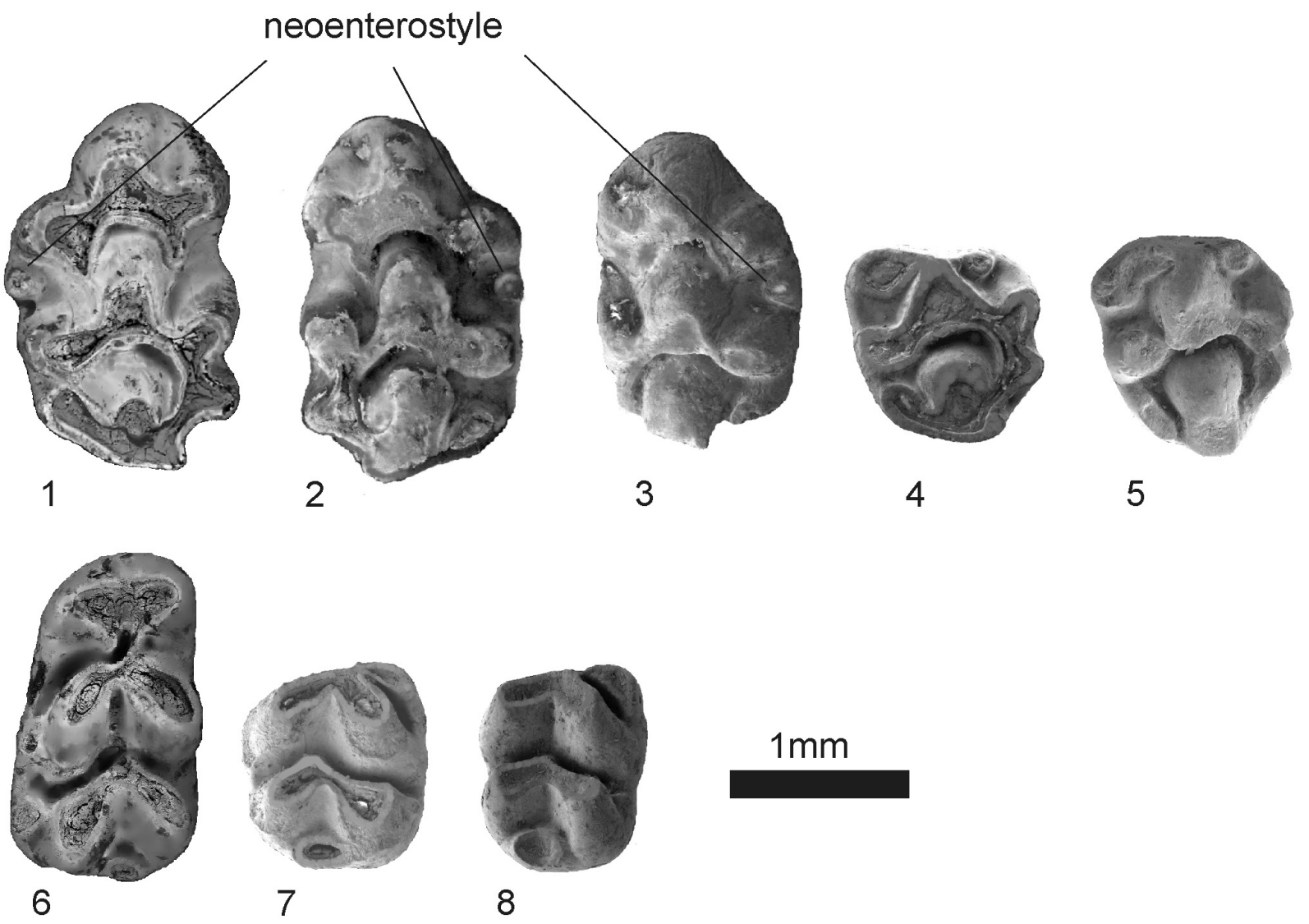

FIGURE 3. Occlusal views of Extrarius orhuni nov. gen. and sp. from Gökpınar (GOP). 1, left M1 (GOP-5001); 2, right M1 (GOP-5002); 3, right M1 (GOP-5003); 4, left M2 (GOP-5004); 5, left M2 (GOP-5005); 6, left m1 (GOP-5006); 7, right m2 (GOP-5007); 8, right m2 (GOP-5008).

between $\mathrm{t} 1-\mathrm{t} 5$ and $\mathrm{t} 3-\mathrm{t} 5$. Whereas a strong and garland-type of connection exists between t4-t5-t6-t9t8 and $t 7$ in one of the specimens (GOP 5001), there exists no connection of $t 4-\mathrm{t} 7$ in the other two specimens (Figure 3.2-3). $\mathrm{t} 1$ and $\mathrm{t} 3$ are almost symmetrical, like $t 4$ and $t 6$. A circular island shaped strong neoenterostyle exists in all specimens in the lingual parts of the teeth. The posteroloph is weak. There are three roots.

M2. There are two specimens, one of which (GOP 5005 ) is worn while the other (GOP 5004) is not. The $\mathrm{t} 1$ is oval, large and has a strong connection with $\mathrm{t} 5$. The $\mathrm{t} 3$, round, is smaller and lower than $\mathrm{t} 1$ and is connected to t5. A strong and garland-type of connection exists between $\mathrm{t} 4-\mathrm{t} 5-\mathrm{t} 6-\mathrm{t} 9-\mathrm{t} 8$ and $\mathrm{t} 7$ in the worn specimen. There exists no connection of t4-t7 in the other specimen.

m1. Only one $\mathrm{m} 1$ was found (GOP 5006). The tma is absent. The connection between the labial-lingual anteroconids is stronger than the connection between protoconid-metaconid. There is a weak connection between lingual anteroconid-metaco- nid, but no connection exists between labial anteroconid and protoconid. The hypoconid-entoconid connection is quite strong; the entoconid is linked to the metaconid by a thin ridge. The posteroconid is observed in the form of an oval island on the posterior part of the tooth. The c1 and c2 are connected to each other. There are two roots. m2. There are two specimens (GOP 5007-5008). In both specimens, the anterior side is slightly wider than the posterior end. The anterolabial cuspid is large, oval and has a connection with the protoconid. There is no labial cingulum in our specimens. The posterior tubercule is shaped in the form of an enamel island, and it has a weak connection with the hypoconid. There are two roots.

\section{COMPARISON}

We have compared our specimens with the other murids of Gökpınar in order to find out if they are intraspecific variations. Two Muridae species, Mus denizliensis and Apodemus sylvaticus/flavicol- 


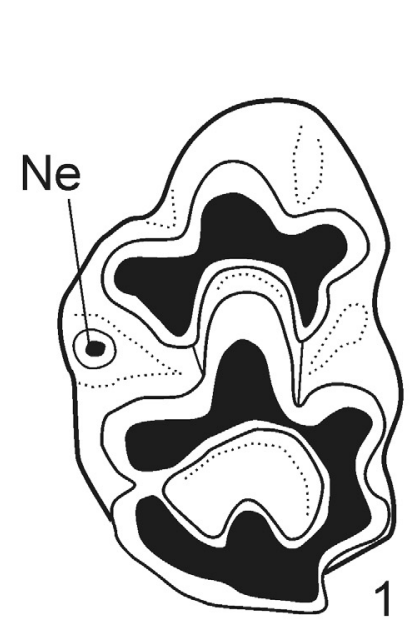

\section{neoenterostyle $(\mathrm{Ne})$}
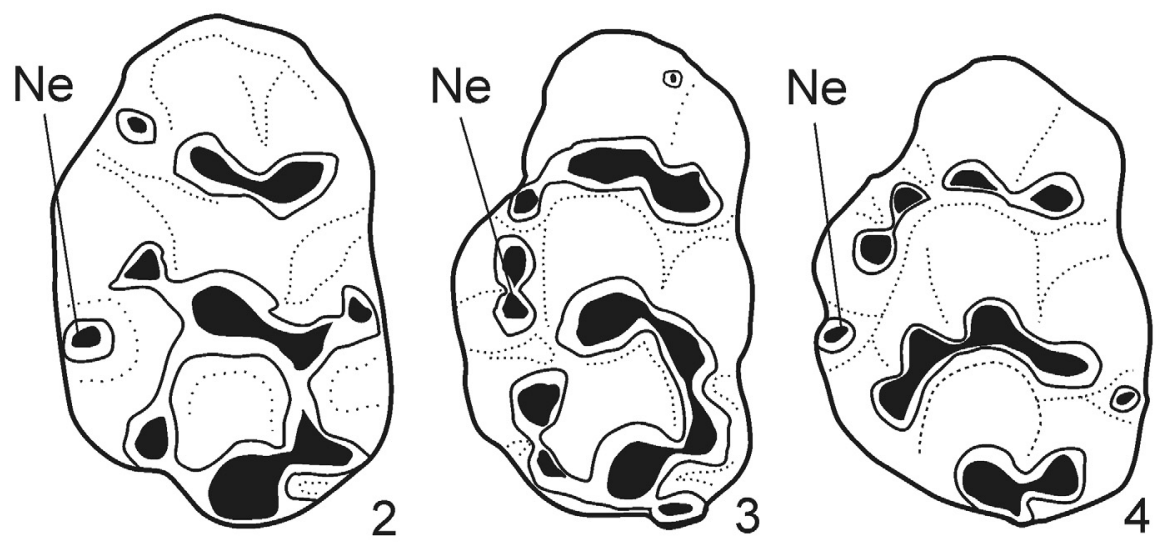

FIGURE 4. Comparison of the species that have neoenterostyle in upper first molars. 1, Gökpınar locality (GOP5001); 2, Orientalomys cf. similis from Pliocene aged Ertemte in Inner Mongolia, China (Storch 1987, plate 3); 3, Leilaomys zhidingi from Late Miocene aged Yunnan Province, China (Storch and Ni 2002, figure 2.6); 4, Progonomys clauzoni from Late Miocene, eastern France (Lazzari et. al., 2010, figure 1.1). The length of teeth has been made the same in order to facilitate morphological comparison and to draw attention to differences in shape.

lis, have been described from Gökpınar (Erten et al., 2015). Unlike this new form, in Mus denizliensis, neither a garland connection between t4-t5-t6t9-t8 nor longitudinal crests are observed on M1. Therefore, these specimens cannot enter in the intraspecific variation of this species. Apodemus sylvaticus-flavicollis has a garland connection between $\mathrm{t} 4-\mathrm{t} 5-\mathrm{t} 6-\mathrm{t} 9$-t8 on M1similar to the specimens described here. However, A. sylvaticus-flavicollis lacks the neoenterostyle and longitudinal crests on the M1, has a strong posteroloph, and its $\mathrm{m} 1$ has a strong tma. Thus, these three molars cannot enter in the intraspecific variation of this species, either.

There are only three species with neoenterostyle: Leilaomys zhudingi (Storch and Ni, 2002), Orientalomys cf. similis (Storch, 1987) and Progonomys clauzoni (Lazzari et al., 2010) (Figure 4). In addition, the genera Apodemus and Stephanomys share with the Gökpınar specimens the stephanodont pattern in the $M 1$, the garland connections of cusps t4-t5-t6-t9-t8 and the crest connections between $\mathrm{t} 1-\mathrm{t} 5$ and $\mathrm{t} 3-\mathrm{t} 5$.

The genus Leilaomys has only one species, Leilaomys zhudingi Storch and Ni, 2002 (Late Miocene, Yunnan Province, China). In the M1 of this species, the $\mathrm{t} 1$ is situated posteriorly to $\mathrm{t} 2 \mathrm{-t} 3$ and it is connected by a long cingulum-like ridge with $\mathrm{t} 2$. Moreover, there is a strong connection between t2t3 (Figure 4). On the M1s from Gökpınar t1, t2 and $\mathrm{t} 3$ have a strong connection and the $\mathrm{t} 1$ is not situated backward to t2-t3. In addition, the M1 of Lei- laomys does not possess a garland-type of connection between t4-t5-t6-t9-t8 and $\mathrm{t} 7$ as on the Gökpınar sample. In Leilaomys t4 is isolated from $\mathrm{t} 5$, and the posteroloph is well developed (Figure 4). As a result, the Gökpınar specimens cannot be referred to the genus Leilaomys.

Since the Gökpınar M1s have a strong connection between $\mathrm{t} 1$ and $\mathrm{t} 2 \mathrm{t} \mathrm{t} 3$ and one of them (GOP 5001) has a strong garland-type connection between t4-t5-t6-t9-t8 and t7, they are different from the cusp organisation seen in Orientalomys. Orientalomys cf. similis (Pliocene aged Ertemte in Inner Mongolia, China in Storch, 1987) has a neoenterostyle similar to that of Gökpınar specimens. Yet, in contrast to our specimens, $\mathrm{t} 1$ and $\mathrm{t} 4$ are far posterior in position, $\mathrm{t} 1$ is widely separated from $\mathrm{t} 2$, there is connection between $\mathrm{t} 5$ and $\mathrm{t} 7$ and longitudinal crests are not observable in this genus (Figure 4). Therefore, the Gökpınar specimens show clear differences when compared with this species.

In the genus Progonomys, the t6 and t9 are separated and there is no t7 (Freudenthal and Martín Suárez, 1999). The Gökpınar M1s display a strong connection between $t 6$ and $t 9$, and a welldeveloped $t 7$ connected to t8. Consequently, the Gökpınar specimens cannot be included in this genus. Lazzari et al. (2010) stated in their study on Progonomys clauzoni (Late Miocene, Lo Fournas $16 \mathrm{M}$ locality, France) that neoenterostyle exists in 5 out of 38 M1 specimens. In contrast to our specimens, the connection between $\mathrm{t} 1, \mathrm{t} 2$ and $\mathrm{t} 3$ is weak in this species, there is no connection between $t 6$ 
and $\mathrm{t} 9$, and the longitudinal crests are missing. Thus, the Gökpınar specimens cannot be included in this species, either.

The genus Apodemus shows the most similarity to our specimens because of the stephanodont pattern of $\mathrm{M} 1$, and the presence of a crest connecting t4-t8, and also cingular cuspids (c1, c2 and c3) on the m1 (Freudenthal and Martín Suárez, 1999; Storch, 2004). However, in contrast to the Gökpinar specimens, the posteroloph on M1 and the tma on $\mathrm{m} 1$ are well developed, and there are not any longitudinal crest connections between $\mathrm{t} 1-\mathrm{t} 5$, $\mathrm{t} 3-\mathrm{t} 5$ in fossil and extant species of Apodemus. Furthermore, since neoenterostyle does not exist in any of Apodemus species, the Gökpınar specimens cannot be included in this genus.

The genus Stephanomys shares with the Gökpınar specimens the stephanodont pattern of $M 1$, the continuous garland of cusps t4-t5-t6-t9-t8 and the longitudinal crest connections between $\mathrm{t} 1$ $\mathrm{t} 5$, t3-t5. Yet, our specimens have moderately developed longitudinal connections between the tubercles on M1s and a less pronounced stephanodonty when compared to Stephanomys. The $\mathrm{t} 1$ bis or t4 bis, which exists on M1 in all Stephanomys species, does not exist in our specimens, and finally the neoenterostyle is seen in none of the species referred to this genus. Because of these differences, the Gökpınar specimens cannot be attributed to any of these genera.

Therefore, the Gökpınar specimens have been described as Extrarius orhuni nov. gen. and $\mathrm{sp}$. because of the presence of neoenterostyle, moderately developed longitudinal connections between the cusps and their garland organization in $\mathrm{M} 1$, the lack of tma and the presence of a crest between the entoconid and metaconid on $\mathrm{m} 1$.

\section{DISCUSSION}

Renaud et al. (2005) and Rodrigues et al. (2013) divided the murid genera into two groups according to their stephanodonty and garland characteristics. These groups are the Progonomys hispanicus-Occitanomys-Stephanomys lineage, which has both stephanodonty and garland characteristics, and the Progonomys-Apodemus lineage, which shows only garland characteristics. Nevertheless, Lazzari et al. (2010) distinguished Progonomys clauzoni-Leilaomys zhidingi-Orientalomys cf. similis lineage out of the murids based on the presence of a 'neoenterostyle', as the M1 from Gökpınar have. Both stephanodonty and garland characteristics exist in our M1 specimens, indicating their affinity with the Progonomys hispanicus-
Occitanomys-Stephanomys lineage. However, the members within lineage lack the neoenterestyle contrary to the M1s from Gökpınar. Therefore, the Gökpınar specimens are similar to the Progonomys clauzoni- Leilaomys zhidingi- Orientalomys cf. similis lineage, but in all three species included in this lineage the M1 is not stephanodont and the cusps are not grouped in a garland (Figure 4). So, it is clear that the Gökpınar specimens are different from this group. Mansino et al. (2015) described the species Paraethomys meini from the localities he dated as Miocene-Pliocene. He indicated in his study that 1 out of 16 M1 specimens had neoenterostyle. In contrast to our specimens, t2-t3 are closer to each other compared to the t1-t2 and there is no crest connection between $\mathrm{t} 1$-t 5 and $\mathrm{t} 3-$ t5 in these species. The available data on fossil murids do not allow the proposal any reliable hypothesis on the origin and relationships of Extrarius.

\section{ACKNOWLEDGEMENTS}

I am grateful to Dr. S. Sen (Muséum National d'Histoire Naturelle, Paris) for improving various aspects of this paper through critical reading and for his contribution to improve the presentation of it. J. Louys and anonymous reviewers are acknowledged for their critical comments and contributions, which greatly improved the paper. My final thanks are for my parents and especially my wife M.U. Erten, who contributed to this study by checking my English writing.

\section{REFERENCES}

Boulbes, N., Mayda, S., Titov, V.V., and Alçiçek, M.C. 2014. Les grands mammifères pléistocènes des travertins du Bassin de Denizli, Sud-ouest de l'Anatolie, Turquie. Anthropologie, 118:44-73.

Bowditch, T.E. 1821. An Analysis of the Natural Classifications of Mammalia for the Use of Students and Travelers. J. Smith, Paris, France.

Bozkurt, E. 2003. Origin of NE-trending basins in western Turkey. Geodinamica Acta, 16:61-81.

Cordy, J.M. 1976. Essai sur la microévolution du genre Stephanomys, Rodentia Muridae. Unpublished Ph.D. Thesis, Université de Liège, Faculté des Sciences, Belgium.

Erten, H. 2014. Denizli karasal Neojen-Kuvaterner havzasının (güneybatı Türkiye) küçük memeli fosilleri ile biyokronolojik incelemesi. Ph.D. thesis, Süleyman Demirel Üniversitesi, Mühendislik ve Mimarlık Fakültesi Jeoloji Mühendisliği bölümü, Turkey.

Erten, H., Sen, S., and Görmüs, M. 2014. Middle and late Miocene Cricetidae (Rodentia, Mammalia) from Denizli Basin (south-western Turkey) and a new spe- 
cies of Megacricetodon. Journal of Paleontology, 88(3):504-518.

Erten, H., Sen, S., and Özkul, M. 2005. Pleistocene mammals from travertine deposits of the Denizli Basin (SW Turkey) Annales de Paléontologie, 91(3):267-278

Erten, H., Sen, S., and Sagular, E.K. 2015. Miocene and early Pleistocene rodents (Mammalia) from Denizli Basin (Southwestern Turkey) and a new species of fossil Mus. Journal of Vertebrate Paleontology, DOI: 10.1080/02724634.2015.1054036.

Freudenthal, M. and Martín Suárez, E. 1999. Family Muridae, p. 401- 409. In Rössner, G.E. and Heissig, K. (eds.), The Miocene Land Mammals of Europe. Dr. Friedrich Pfeil, München.

Gray, J.E. 1821. On the natural arrangement of vertebrose animals. London Medical Repository, 15:296310.

Kappelman, C., Alçiçek, M.C., Kazancı, N., Schultz, M., Özkul, M., and Sen, S. 2008. Brief communication: first Homo erectus from Turkey and implications for migrations into temperate Eurasia. American Journal of Physical Anthropology, 135:110-116.

Lazzari, V., Aguilar, J.P., and Michaux, J. 2010. Intraspecific variation and micro-macroevolution connection: illustration with the late Miocene genus Progonomys (Rodentia, Muridae). Paleobiology, 36:641-657.

Lebatard, A.E., Alçiçek, M.C., Rochette, P., Khatib, S., Vialet, A., Boulbes, N., Bourlès, D.L., Demory, F., Guipert, G., Mayda, S., Titov, V.V., Vidal, L., and de Lumley, H. 2014. Dating the Homo erectus bearing travertine from Kocabas (Denizli, Turkey) at least 1.1 Ma. Earth and Planetary Science Letters, 390:8-18.

Mansino, S., Javier Ruiz-Sánchez, F., Fierro, I., and Montoya, P. 2015. Mio-Pliocene rodent assemblages from Alcoi Forn (Alcoy Basin, Eastern Spain). Biostratigraphical and palaeoclimatical inferences. Historical Biology,

DOI: 10.1080/08912963.2015.1102238

Özkul, M., Kele, S., Gökgöz, A., Shen, C.C., Jones, B., Baykara, M.O., Fórizs, I., Nemeth, T., Chang, Y.W., and Alcçicçek, M.C. 2013. Comparison of the Quaternary travertine sites in the Denizli Extensional Basin based on their depositional and geochemical data. Sedimentary Geology, 294:179-204.

Renaud, S., Michaux, J., Schmidt, D.N., Aguilar, J.P., Mein, P., and Auffray, J.C. 2005. Morphological evolution, ecological diversification and climate change in rodents. Proceedings of the Royal Society of London, B, Biological Sciences, 272:609-617.

Rodrigues, H.G., Renaud, S., Charles, C., Le Poul, Y., Sole, F., Aguilar, J.P., Michaux, J., Tafforeau, P., Headon, D., Jernvall, J., and Viriot, L. 2013. Roles of dental development and adaptation in rodent evolution. Nature Communications, 4:2504.

Şimşek, Ş. 1984. Denizli-Kızıldere-Tekkehamam-Tosunlar-Buldan-Yenice alanının jeolojisi ve jeotermal enerji olanakları. Maden Tetkik Arama Raporu, 7846.

Storch, G. 1987. The Neogene mammalian faunas of Ertemte and Harr Obo in Inner Mongolia (Nei Mongol), China. 7. Muridae (Rodentia). Senckenbergiana Lathaea, 67:401-431.

Storch, G. and. Ni, X.J. 2002. New Late Miocene murids from China (Mammalia, Rodentia). Geobios, 335:515-521.

Storch, G. 2004. The fossil history of Murinae (Rodentia), in particular of Apodemus. In Maul, L.C. and Kahlke, R.-D. (eds.), $18^{\text {th }}$ International Senckenberg Conference in Weimar. Terra Nostra, 2:242-243. 